\title{
BLOCKCHAIN DAN KECERDASAN BUATAN DALAM PERTANIAN : STUDI LITERATUR
}

\author{
Fajar Delli Wihartiko*1, Sri Nurdiati², Agus Buono ${ }^{3}$, Edi Santosa ${ }^{4}$ \\ ${ }^{1}$ Departemen Ilmu Komputer, Institut Pertanian Bogor \& Program Studi Ilmu Komputer, Universitas Pakuan. \\ ${ }^{2}$ Departemen Matematika, Institut Pertanian Bogor, ${ }^{3}$ Departemen Ilmu Komputer, Institut Pertanian Bogor. \\ ${ }^{4}$ Departemen Agronomi dan Hortikultura, Institut Pertanian Bogor. \\ Email: ${ }^{1}$ fajardelli@apps.ipb.ac.id, ${ }^{2}$ nurdiati@apps.ipb.ac.id, \\ ${ }^{3}$ agusbuono@apps.ipb.ac.id, ${ }^{4}$ edisang@gmail.com \\ *Penulis Korespondensi
}

(Naskah masuk: 11 September 2020, diterima untuk diterbitkan: 02 Februari 2021)

\begin{abstract}
Abstrak
Dewasa ini teknologi blockchain dan kecerdasan buatan (artificial intelligence/AI) telah diimplementasikan dalam bidang pertanian. Teknologi blockchain menjanjikan keamanan dan peningkatan kepercayaan untuk pengguna. Teknologi kecerdasan buatan menjanjikan berbagai kemudahan bagi pengguna. Perpaduan kedua teknologi tersebut dapat meningkatan kepercayaan terhadap sistem kecerdasan buatan (blockchain for AI) atau dapat juga digunakan untuk meningkatkan kinerja sistem blockchain (AI for blockchain). Tujuan penelitian ini mengulas kedua teknologi tersebut dalam studi literatur serta memberikan tantangan riset ke depan terkait implementasinya di bidang pertanian. Metodologi yang digunakan adalah Systematic Literature Review (SLR) dan text mining. Text mining digunakan untuk memberikan deskripsi riset yang ada berdasarkan kata-kata di setiap artikel terpilih. SLR digunakan untuk memberikan ulasan yang komprehensif terkait riset Blockchain dan kecerdasan Buatan dalam pertanian. Hasil penelitian menunjukan bahwa terdapat $10 \%$ penelitian terkait penerapan blockchain dan AI dalam pertanian. Riset tersebut memiliki potensi besar untuk berkembang terlihat dari peningkatan jumlah publikasi dalam 2 tahun terakhir. Kontribusi penelitian ini meliputi posisi riset terkini dan usulan riset ke depan dengan mempertimbangkan kondisi pertanian Indonesia. Posisi riset tersebut didominasi komunitas peneliti dari negaranegara di Asia seperti India (33\%), Pakistan (33\%), China (14\%) dan Korea (14\%). Originalitas penelitian ini terletak pada studi literatur dari integrasi teknologi blockchain dan kecerdasan buatan dalam bidang pertanian menggunakan SLR dan text mining.
\end{abstract}

Kata kunci: blockchain, kecerdasan buatan, pertanian

\section{BLOCKCHAIN AND ARTIFICIAL INTELLIGENCE IN AGRICULTURE : A SYSTEMATIC LITERATURE REVIEW}

\begin{abstract}
Artificial intelligence and blockchain technology are being developed and implemented in Agriculture. Blockchain technology promises security and trust for users. Moreover, artificial intelligence technology promises convenience for users. The combination of these two technologies will increase trust in artificial intelligence systems. Besides, this combination can also increase security on the blockchain system through the application of artificial intelligence. This paper summarizes the application of both technologies and reviews them in a systematic literature review, presents a description of articles based on text mining, and provides future research challenges related to the implementation of blockchain and artificial intelligence in agriculture. The methodologies used are Systematic Literature Review (SLR) and text mining. Text mining is used to describe a description of existing research based on the words in each selected article. SLR is used to provide a comprehensive review of Blockchain research and Artificial intelligence in agriculture. The results showed that there were $10 \%$ of research related to the application of blockchain and AI in agriculture. This research has great potential for growth as seen from the increase in the number of publications in the last 2 years. The contribution of this research includes the latest research positions and future research proposals taking into account the conditions of Indonesian agriculture. The research position is dominated by the research community from countries in Asia such as India (33\%), Pakistan (33\%), China (14\%) and Korea (14\%). The originality of this research is a literature study on the integration of blockchain and artificial intelligence in agriculture using SLR and text mining.
\end{abstract}

Keywords: blockchain, Artificial intelligence, agriculture 


\section{PENDAHULUAN}

Blockchain dan kecerdasan buatan saat ini telah berkembang dengan pesat di era revolusi industri 4.0. Keduanya memiliki peran yang berbeda namun dapat saling melengkapi. Salah satu fitur utama dari blockchain adalah immuttability yang merupakan fitur untuk keamanan data agar tidak dapat diubah oleh seorang pengguna. Perubahan data dalam sistem blockchain mungkin dilakukan atas persetujuan suatu konsensus. Berikutnya kecerdasan buatan (Artificial Intelligence/AI) memiliki keunggulan yang terletak pada kemampuannya dalam hal meniru kecerdasan manusia seperti pada proses pembelajaran dan penyelesaian masalah. Perpaduan antara blockchain dan kecerdasan buatan akan menjadi revolusi untuk generasi digital (Dinh \& Thai, 2018) dan akan banyak diterapkan dalam berbagai bidang termasuk dalam bidang pertanian.

Teknologi blockchain menawarkan keamanan data untuk meningkatkan kepercayaan pengguna melalui sistem data terdistribusi. Blockchain juga memiliki kemampuan untuk mengotomatisasi pembayaran dalam cryptocurrency, menyediakan akses data transaksi secara desentralisasi yang aman dan tepercaya (Salman et al., 2019), (Yadaf \& Singh, 2019), (Zheng et al., 2017). Teknologi blockchain pertama kali dikenalkan melalui sistem bitcoin (Nakamoto, 2008) dan terus berkembang baik dalam hal manajemen, privasi, keamanan dan tata kelola data hingga diaplikasikan untuk meningkatkan kepercayaan sistem pada bidang kesehatan, pendidikan, bisnis, industri, manajemen rantai pasok dan keuangan (Casino, Dasaklis \& Patsakis, 2019), (Dave et al., 2019), (Casado et al., 2018).

Teknologi kecerdasan buatan menawarkan kemudahan bagi pengguna di antaranya melalui berbagai macam teknik pembelajaran dan optimasi melalui konsep machine learning dan swarm intelligence. Kecerdasan buatan sendiri didefinisikan sebagai suatu mesin atau program yang memiliki kecerdasan di dalamnya guna menyelesaikan suatu pekerjaan (Dinh \& Thai, 2018). Konsep kecerdasan buatan mulai dikenal oleh masyarakat awam saat kemenangan deep blue (pemograman catur berbasis kecerdasan buatan) atas Garry Kasparov (juara dunia catur) dalam permainan catur, meskipun teknologi AI mulai dirintis oleh John McCarthy (1927) (Vardi, 2012). Berbagai penerapan teknologi kecerdasan buatan diantaranya meliputi pengembangan sistem pakar, robotic, pengenalan suara, computer vision, artificial neural network dan sistem fuzzy (Singh, Rathore \& Park, 2019), (Bannerjee et al., 2018).

Era revolusi industri 4.0 telah mendorong penerapan teknologi informasi di berbagai bidang termasuk dalam pertanian yang mendorong era agromaritim 4.0 (IPB，2019) (Klerkx, Jakku \& Labarthe, 2019). Bidang pertanian sendiri akan terus berkembang mengingat pertanian merupakan kebutuhan mendasar dari manusia. Hal ini terlihat dalam data Food and Agriculture Organization
(FAO) of the United Nations (FAO, 2019) yang menunjukkan peningkatan produksi pertanian pada skala dunia yakni sebesar $4,1 \%$ di dekade terakhir. Teknologi kecerdasan buatan dalam agromatirim 4.0 umumnya digunakan untuk prediksi hasil panen, deteksi penyakit tanaman, manajemen tanaman, pengendalian hama, pengendalian penyakit, manajemen irigasi, manajemen nutrisi tanah, pemantauan produksi dan pemantauan penyimpanan produk pertanian (Liakos et al., 2018), (Bannerjee et al., 2018). Implementasi blockchain dalam pertanian mayoritas digunakan dalam penyelesaian masalah manajemen rantai pasok serta sebagai media penyimpanan data dalam sistem Internet of Things (IOT) (Almeida et al., 2018), (Ge et al., 2017), (Kim \& Laskowski, 2018).

Penelitian Systematic Literature Review (SLR) untuk teknologi blockchain di bidang pertanian ditemukan dalam kurun waktu 2018-2020. Penelitian tersebut diinisialisasi oleh (Almeida et al., 2018) dengan hasil dominasi penelitian blockchain ada pada kasus manajemen rantai pasok pertanian. Selain itu penerapan teknologi blockchain di pertanian di dominasi oleh komuniatas peneliti dari Asia, dalam hal ini ada pada negara China. Penelitian (Yadaf \& Singh, 2019) juga memperkuat penelitian sebelumnya dimana riset masih didominasi oleh Asia. Penelitian tersebut mengungkapkan bahwa topik utama riset blockchain dalam pertanian adalah mengenai ketertelusuran rantai pasok pertanian. Berbeda dengan hal tersebut, penelitian (Kasten, 2020) berfokus pada SLR untuk keamanan pangan, proses produksi serta pengiriman produk.

Penelitian mengenai tinjauan pustaka terkait penerapan blockchain dalam pertanian dipertajam dengan ruang lingkup yang lebih spesifik dan dengan penambahan metode lain. Sepertihalnya penelitian (Antonucci et al., 2019) menggunakan analisis pemetaan dalam mempelajari penelitan blockchain untuk produk agrifood dalam perspektif komputasi dan aplikasi. Penelitian tersebut juga mengulas faktor-faktor ketidakpastian yang harus diperhatikan dalam memperkuat struktur blockchain dalam sektor agrifood. Penelitian (Mirabelli \& Solina, 2020) berfokus untuk ketertelusuran manajemen rantai pasok pertanian dimana dalam analisa deskripsinya menggunakan analisa jaringan dari kata-kata yang muncul dalam artikel ada. Beberapa kata yang dominan meliputi smart agriculture, Internet of Things (IOT), sustainability, traceability serta etherium \& smart contract. Hasil penelitian menunjukan bahwa teknologi blockchain di pertanian telah berkembang dengan pesat yang dilihat dari jumlah riset yang ada.

Berbagai ulasan mendalam terkait penerapan blockcchain dalam pertanian juga telah tersedia. Seperti pada penelitian (Demestichas et al., 2020) mengulas penggunaan blockchain dalam sistem ketertelusuran di pertanian. Hasil penelitian tersebut menunjukan penggunaan blockchain dapat 
meningkatkan sistem ketertelusuran yang ada melalui penyimpanan data secara permanen. Berikutnya penelitian (Xiong et al., 2020) telah melakukan pembahasan mengenai aspek teori dan aplikatif dari implementasi blockchain pada kasus rantai pasok makanan, asuransi produk pertanian, konsep pertanian cerdas dan transaksi produk pertanian. Ulasan mendalam mengenai teknik yang digunakan untuk penerapan blockchain dalam pertanian dibahas oleh (Lin et al., 2020). Pembahasannya meliputi elemen teknis (struktur data, kriptografi, konsensus), aplikasi, platform serta smart contract. Penelitian tersebut juga mengusulkan penerapan blockchain pasca pandemi Covid-19. Ulasan terkait penggunaan blockchain untuk keamanan pangan dibahas pada penelitian (Wang \& Yang, 2020). Pembahasan meliputi permasalahan yang mungkin muncul dalam implementasi blockchain seperti infrastuktur, biaya serta regulasi.

Berdasarkan penelitian studi literatur di atas, belum ditemukan studi literatur mengenai implementasi blockchain dan kecerdasan buatan secara bersamaan di bidang pertanian. Mayoritas penelitian studi literatur yang ada berupa kajian dari implementasi kedua teknologi tersebut secara terpisah dan studi mengenai konsep kedua teknologi tersebut di bidang pertanian. Berbeda dengan hal tersebut artikel ini menyajikan kajian literatur mengenai penerapan integrasi teknologi blockchain dan kecerdasan buatan serta memberikan potensi pengembangan riset sesuai kondisi di Indonesia. Kontribusi artikel terletak pada posisi riset terkini serta usulan riset ke depan mengenai penerapan kedua teknologi tersebut di bidang pertanian. Tujuan artikel ilmiah ini adalah meninjau penerapan teknologi blockchain dan kecerdasan buatan pada pertanian serta melihat peluang penerapan kedua teknologi tersebut secara bersama-sama pada bidang pertanian. Originalitas riset berupa studi literatur menggunakan SLR dan text mining dalam tema blockchain dan kecerdasan buatan di bidang pertanian. Struktur penulisan artikel ini secara berurut meliputi pendahuluan, penelitian sebelumnya, metodologi, hasil dan pembahasan serta kesimpulan.

\section{METODE PENELITIAN}

Penelitian ini menggunakan Systematic Literature Review (SLR) dengan text mining untuk analisa deskriptif. SLR digunakan untuk memberikan gambaran yang komprehensif terkait topik penelitian (Xiao \& Watson, 2019). Text mining digunakan untuk memberikan gambaran umum artikel yang terkumpul berdasarkan kata-kata yang ada di seluruh artikel (O'Mara-Eves et al., 2015). Dalam studi literatur ini, proses text mining digunakan untuk memperkuat hasil yang diperoleh dari SLR. Proses SLR dengan text mining yang digunakan dalam studi ini merupakan pengembangan proses SLR (Xiao \& Watson, 2019). Secara rinci proses tersebut dapat dilihat dalam Gambar 1.

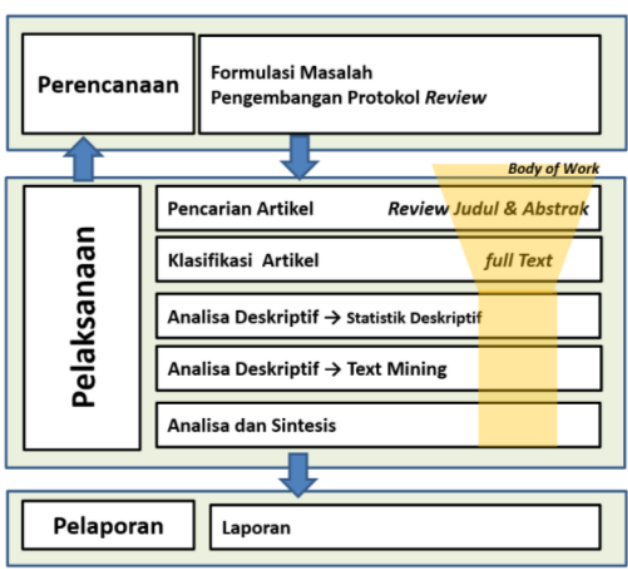

Gambar 1. Proses SLR dengan Text Mining

\subsection{Proses Perencanaan}

Pedoman yang digunakan dalam proses pencarian dan proses klasifikasi artikel secara umum adalah sebagai berikut :

(1) kata kunci pencarian yang digunakan meliputi blockchain, blockchain ai, blockchain artificial intelligence dan blockchain agriculture.

(2) Artikel terbaru (2016 - 2020) bereputasi dan terindeks.

(3) Proses pengelompokan dilakukan dengan mengklasifikasikan artikel dalam subtopik. Jika terdapat 1 artikel ilmiah dengan subtopik lebih dari 1, maka akan dipilih satu subtopik yang dominan.

\subsection{Proses Pelaksanaan}

Statistika deskriptif digunakan untuk melihat gambaran mengenai posisi penelitian blockchain dan kecerdasan buatan dalam pertanian. Hasil artikel yang terkumpul disajikan dalam bentuk diagram dan grafik untuk mempermudah proses analisis.

Text mining dalam tahap ini digunakan untuk memberikan deskripsi penelitan blockchain dan kecerdasan buatan dalam pertanian. Proses text mining menggunakan software NVIVO 12 terhadap jurnal yang memiliki kesesuaian dengan topik penelitian. Hasil text mining berupa word of cloud dan pohon clustering.

Proses sintesa dilakukan berdasarkan hasil analisa deskriptif. Dalam tahap ini dilakukan pembahasan mengenai kontribusi artikel terhadap bidang pertanian serta kendala-kendala yang ditemukan. Pengembangan usulan riset terkait penerapan blockchain dan kecerdasan buatan dalam pertanian disusun dengan mempertimbangkan hasil studi literatur dan juga berdasarkan kondisi pertanian yang ada di Indonesia. 


\section{HASIL DAN PEMBAHASAN}

\subsection{Hasil Pencarian dan Klasifikasi Artikel}

Dari hasil pencarian sesuai kata kunci, diperoleh data berupa artikel ilmiah dalam bentuk jurnal dan proceeding dengan jumlah sebanyak 58 buah. Artikel ilmiah tersebut diterbitkan pada tahun 2016 Agustus 2020 serta memiliki tema besar blockchain dalam pertanian. Artikel ilmiah yang terkumpul kemudian diklasifikasi kembali berdasarkan subtopik artikel ilmiah yang secara umum terbagi dalam 5 kelompok. Pemilihan subtopik di setiap kelompok dilakukan berdasarkan pengembangan dari penelitian (Yadaf \& Singh, 2019) yakni :

(1) Ulasan penerapan blockchain di pertanian (Survey).

(2) Implementasi blockchain dalam masalah manajemen rantai pasok (Supply Chain Management/SCM) di pertanian.

(3) Implementasi blockchain sebagai data base (DB) di bidang pertanian.

(4) Integrasi blockchain dan Internet of Things (IOT) di pertanian.

(5) Integrasi blockchain dan Kecerdasan Buatan (AI) di pertanian.

Hasil pengelompokan dan pengumpulan artikel ilmiah tersebut disajikan dalam Tabel 1.

\subsection{Hasil Analisa Deskriptif}

Diagram dan grafik digunakan untuk menganalisa posisi riset blockchain dan AI dalam pertanian. Gambar 2 menunjukan jumlah artikel ilmiah pertahun. Gambar 3 menunjukan persentase hasil klasifikasi dari artikel ilmiah terkait. Gambar 4 menunjukan persentase objek pertanian yang diteliti. Gambar 5 menunjukan lokasi penelitian.

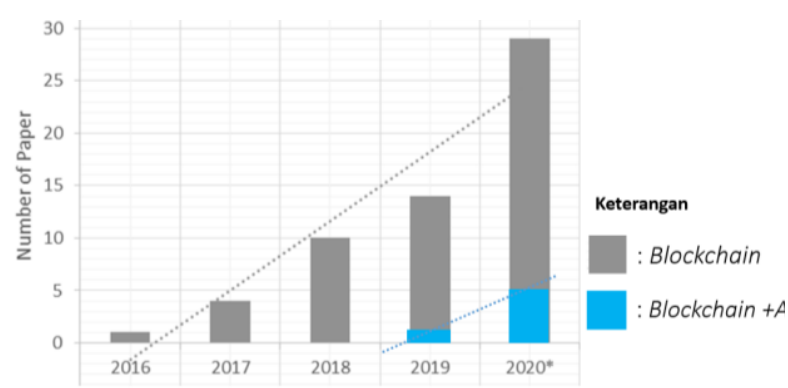

Gambar 2. Jumlah Artikel Ilmiah Terkait per Tahun.

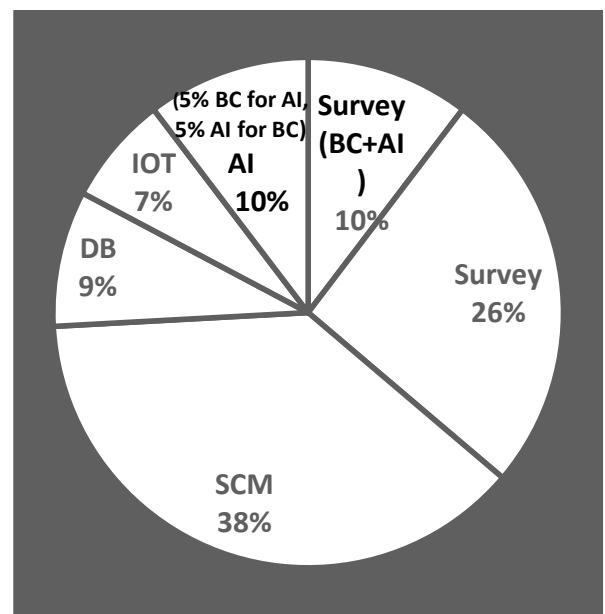

Gambar 3. Persentase Artikel Blockchain Berdasarkan Subtopik
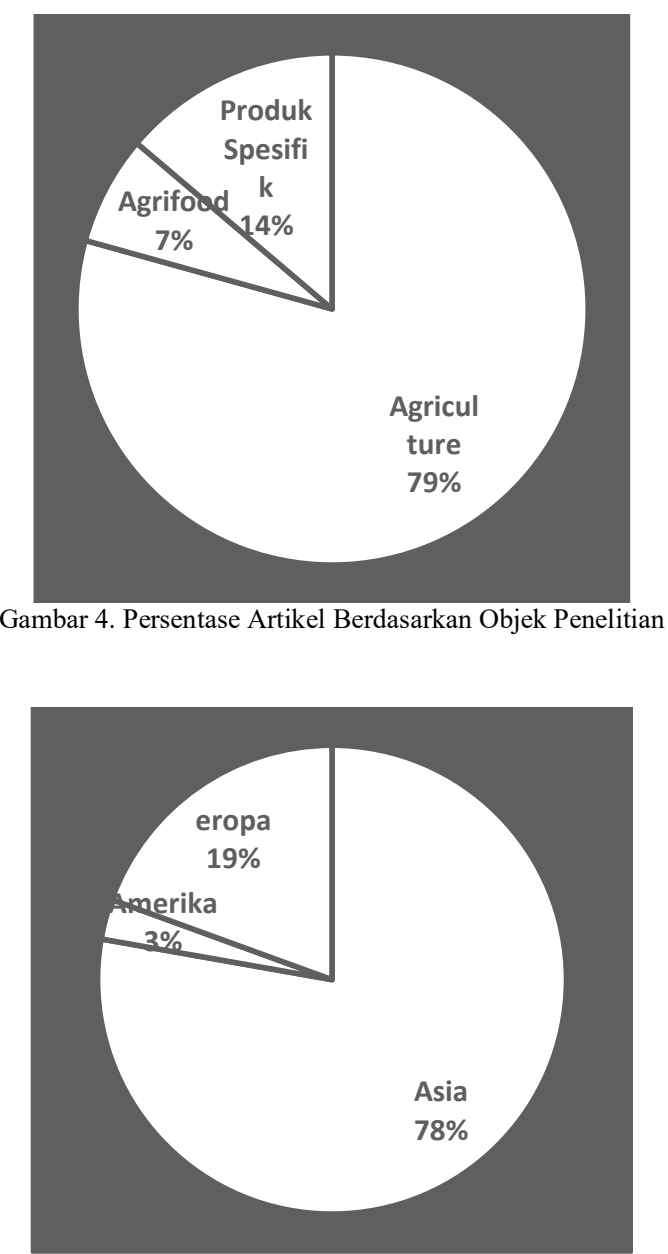

Gambar 5. Persentase Artikel Berdasarkan Lokasi Penelitian 
Tabel 1 Penelitian terkait penerapan blockchain di bidang pertanian

\begin{tabular}{|c|c|c|c|c|c|c|c|c|c|c|}
\hline \multirow{2}{*}{ No } & \multirow{2}{*}{ Sitasi } & \multicolumn{5}{|c|}{ Subtema } & \multicolumn{3}{|c|}{ Objek } & \multirow{2}{*}{ Deskripsi Singkat } \\
\hline & & $\mathbf{a}$ & $\mathbf{b}$ & c & d & $\mathbf{e}$ & $\mathbf{f}$ & $\mathbf{g}$ & $\mathbf{h}$ & \\
\hline 1 & (Tian, 2016) & & $\bullet$ & & & & & $\bullet$ & & $\begin{array}{l}\text { Menggunakan blockchain dan RFID untuk manjemen } \\
\text { rantai pasok makanan di China }\end{array}$ \\
\hline 2 & (Tse et al., 2017) & & $\bullet$ & & & & & $\bullet$ & & $\begin{array}{l}\text { Mengedepankan penerapan teknologi Blockchain dalam } \\
\text { keamanan informasi dari rantai suplai makanan di China }\end{array}$ \\
\hline 3 & (Papa, 2017) & & $\bullet$ & & & & $\bullet$ & & & $\begin{array}{l}\text { Pemanfaatan blockchain untuk transparansi SCM } \\
\text { agribisnis. }\end{array}$ \\
\hline 4 & (Xie, Sun \& Luo, 2017) & & & $\bullet$ & & & $\bullet$ & & & $\begin{array}{l}\text { Merancang skema untuk penyimpanan data berdasarkan } \\
\text { blockchain }\end{array}$ \\
\hline 5 & (Lin et al., 2017) & & & & $\bullet$ & & $\bullet$ & & & Memperkenalkan prototype sistem ICT e-Agriculture \\
\hline 6 & (Salah et al., 2018) & $\bullet$ & & & & & $\bullet$ & & & $\begin{array}{l}\text { Review Blockchain dengan AI dalam berbagai bidang, } \\
\text { termasuk pertanian }\end{array}$ \\
\hline 7 & (Almeida et al., 2018) & $\bullet$ & & & & & $\bullet$ & & & Review Blockchain dalam pertanian \\
\hline 8 & (Rabah, 2018) & $\bullet$ & & & & & $\bullet$ & & & $\begin{array}{l}\text { Memberikan gambaran umum penerapan big data dalam } \\
\text { berbagai bidang }\end{array}$ \\
\hline 9 & (Kumar \& Iyengar, 2018) & & $\bullet$ & & & & & & $\bullet$ & Implementasi blockchain untuk SCM di India \\
\hline 10 & (Leng et al., 2018) & & $\bullet$ & & & & $\bullet$ & & & $\begin{array}{l}\text { SCM pertanian dengan arsitektur rantai ganda berbasis } \\
\text { teknologi blockchain }\end{array}$ \\
\hline 11 & (Lucena et al., 2018) & & $\bullet$ & & & & & & $\bullet$ & $\begin{array}{l}\text { Pelacakan penjaminan mutu gandum berdasarkan } \\
\text { jaringan bisnis blockchain }\end{array}$ \\
\hline 12 & (Carbone et al., 2018) & & $\bullet$ & & & & & • & & $\begin{array}{l}\text { Penerapan teknologi blockchain, cloud dan IOT untuk } \\
\text { rantai pasokan makanan. }\end{array}$ \\
\hline 13 & (Hua et al., 2018) & & $\bullet$ & & & & $\bullet$ & & & $\begin{array}{l}\text { Pemanfaatan blockchain untuk membangun } \\
\text { kepercayaan }\end{array}$ \\
\hline 14 & (Casado et al., 2018) & & $\bullet$ & & & & $\bullet$ & & & $\begin{array}{l}\text { Penggunaan blockchain dalam penerapan industri } \\
\text { pertanian }\end{array}$ \\
\hline 15 & (Patil et al., 2018) & & & $\bullet$ & & & $\bullet$ & & & $\begin{array}{l}\text { Smart greenhouse farm berbasis IOT dengan framework } \\
\text { blockchain }\end{array}$ \\
\hline 16 & (Yadaf \& Singh, 2019) & $\bullet$ & & & & & $\bullet$ & & & Meninjau aplikasi blockchain di bidang pertanian \\
\hline 17 & (Dave et al., 2019) & $\bullet$ & & & & & $\bullet$ & & & $\begin{array}{l}\text { Meninjau aplikasi blockchain di berbagai bidang } \\
\text { termasuk pertanian }\end{array}$ \\
\hline 18 & $\begin{array}{l}\text { (Singh, Rathore \& Park, } \\
\text { 2019) }\end{array}$ & $\bullet$ & & & & & $\bullet$ & & & Konsep BlockIOTIntelligence \\
\hline 19 & (Antonucci et al., 2019) & $\bullet$ & & & & & & $\bullet$ & & Review blockchain dalam agrifood \\
\hline 20 & (Arena et al., 2019) & & $\bullet$ & & & & & & $\bullet$ & $\begin{array}{l}\text { BRUSCHETTA: Blockhain-IOT framework untuk SCM } \\
\text { komoditas minyak zaitun }\end{array}$ \\
\hline 21 & $\begin{array}{l}\text { (Kamble, Gunasekaran \& } \\
\text { Sharma, 2019) }\end{array}$ & & $\bullet$ & & & & $\bullet$ & & & Pemodelan blockchain dalam SCM pertanian \\
\hline 22 & $\begin{array}{l}\text { (Kamilaris, Fonts \& } \\
\text { Prenafeta-Boldó, 2019) }\end{array}$ & & $\bullet$ & & & & & $\bullet$ & & Penerapan blockchain dalam rantai pasokan makanan \\
\hline 23 & (Salah et al., 2019) & & $\bullet$ & & & & & & $\bullet$ & Penerapan blockchain untuk SCM kedelai \\
\hline 24 & $\begin{array}{l}\text { (Reddy, Aravind Reddy \& } \\
\text { Sashi Rekha, 2019) }\end{array}$ & & $\bullet$ & & & & $\bullet$ & & & $\begin{array}{l}\text { Penggunaan Blockchain untuk meningkatkan efisiensi } \\
\text { SCM pertanian }\end{array}$ \\
\hline 25 & (Wu \& Tsai, 2019) & & & & $\bullet$ & & $\bullet$ & & & $\begin{array}{l}\text { Blockchain digunakan untuk pengamanan data jaringan } \\
\text { pada pertanian }\end{array}$ \\
\hline 26 & (Bordel et al., 2019) & & & & $\bullet$ & & $\bullet$ & & & Penggunaan blockchain untuk masalah otomasi irigrasi \\
\hline 27 & $\begin{array}{l}\text { (Munir, Bajwa \& } \\
\text { Cheema, 2019) }\end{array}$ & & & & & $\bullet$ & $\bullet$ & & & $\begin{array}{l}\text { Penggunaan logika fuzzy pada kasus sistem smart } \\
\text { watering menggunakan blockchain }\end{array}$ \\
\hline 28 & $\begin{array}{l}\text { (Nazarov, Shvedov \& } \\
\text { Sulimin, 2019) }\end{array}$ & $\bullet$ & & & & & $\bullet$ & & & $\begin{array}{l}\text { Usulan pengembangan blockchain unuk agro industri } \\
\text { Rusia }\end{array}$ \\
\hline 29 & $\begin{array}{l}\text { (Iswari, Arkeman \& } \\
\text { Muslich, 2019) }\end{array}$ & & $\bullet$ & & & & & & $\bullet$ & $\begin{array}{l}\text { Rancang bangun sistem blockchain untuk rantai pasok } \\
\text { kakao }\end{array}$ \\
\hline 30 & (Ferrag et al., 2020) & $\bullet$ & & & & & & & & Studi literatur penerapan blockchain IOT di pertanian \\
\hline 31 & (Lezoche et al., 2020) & $\bullet$ & & & & & $\bullet$ & & & Studi literatur teknologi di SCM \\
\hline 32 & (Mirabelli \& Solina, 2020) & $\bullet$ & & & & & & & & Studi literatur blockchain dan SCM \\
\hline 33 & (Mistry et al., 2020) & $\bullet$ & & & & & & & & $\begin{array}{l}\text { Review penerapan blockchain di teknologi } 5 \mathrm{G} \text { dan } \\
\text { pertanian secara umum }\end{array}$ \\
\hline 34 & (Sisodiya \& Garg, 2020) & $\bullet$ & & & & & $\bullet$ & & & Review blockchain dan aplikasinya \\
\hline 35 & (Xiong et al., 2020) & $\bullet$ & & & & & $\bullet$ & & & Review implementasi blockchain di pertanian \\
\hline 36 & (Alam et al., 2020) & $\bullet$ & & & & & $\bullet$ & & & Konsep smart farming \& blockchain dalam pertanian \\
\hline 37 & (Borah et al., 2020) & & $\bullet$ & & & & $\bullet$ & & & Penggunaan blockchain dan IOT untuk SCM pertanian \\
\hline 38 & $\begin{array}{l}\text { (Kamble, Gunasekaran \& } \\
\text { Sharma, 2020) }\end{array}$ & & $\bullet$ & & & & $\bullet$ & & & Blockchain dengan SCM untuk keandalan layanan \\
\hline 39 & (Shahid et al., 2020b) & & $\bullet$ & & & & & $\bullet$ & & $\begin{array}{l}\text { Implementasi blockchain untuk SCM berdasarkan } \\
\text { reputasi sitem }\end{array}$ \\
\hline 40 & (Shahid et al., 2020a) & & $\bullet$ & & & & $\bullet$ & & & Solusi blockchain untuk pertanian SCM \\
\hline 41 & (Shingh et al., 2020) & & $\bullet$ & & & & & & $\bullet$ & Pengembangan blockchain pada produk susu murni \\
\hline 42 & (Tiwari, 2020) & & $\bullet$ & & & & & $\bullet$ & & Penerapan blockchain untuk agrifood SCM \\
\hline 43 & $\begin{array}{l}\text { (Daniel \& Ifejika Speranza, } \\
\text { 2020)d }\end{array}$ & & & & $\bullet$ & & $\bullet$ & & & Blockchain untuk dokumentasi data \\
\hline 44 & $\begin{array}{l}\text { (Chinnaiyan \& Balachandar, } \\
\text { 2020) }\end{array}$ & & & $\bullet$ & & & $\bullet$ & & & $\begin{array}{l}\text { Penggunaan blockchain, IOT, drone \& sensor untuk } \\
\text { pertanian }\end{array}$ \\
\hline
\end{tabular}




\begin{tabular}{|c|c|c|c|c|c|c|c|c|c|c|}
\hline \multirow{2}{*}{ No } & \multirow{2}{*}{ Sitasi } & \multicolumn{5}{|c|}{ Subtema } & \multicolumn{3}{|c|}{ Objek } & \multirow{2}{*}{ Deskripsi Singkat } \\
\hline & & $\mathbf{a}$ & $\mathbf{b}$ & c & d & $\mathbf{e}$ & $\mathbf{f}$ & g & $\mathbf{h}$ & \\
\hline 45 & $\begin{array}{l}\text { (Dakshayini \& Balaji Prabhu, } \\
\text { 2020) }\end{array}$ & & & & & $\bullet$ & $\bullet$ & & & $\begin{array}{l}\text { Sistem Penunjang Keputusan berbasis big data dalam } \\
\text { sistem blockchain }\end{array}$ \\
\hline 46 & (Khan, Byun \& Park, 2020) & & & & & $\bullet$ & $\bullet$ & & & $\begin{array}{l}\text { Model RNN untuk prediksi penjualan produk pertanian } \\
\text { dalam sistem blockchain }\end{array}$ \\
\hline 47 & (Yadav et al., 2020) & & & & & $\bullet$ & $\bullet$ & & & Penggunaan fuzzy untuk evaluasi kinerja blockchain \\
\hline 48 & (Kasten, 2020) & $\bullet$ & & & & & $\bullet$ & & & Studi Literatur implementasi blockchain di pertanian \\
\hline 49 & (Awan et al., 2020) & & & & & $\bullet$ & $\bullet$ & & & $\begin{array}{l}\text { Peningkatan kinerja blockchain melalui perutean } \\
\text { protokol dalam sistem IOT-Blockchain pertanian }\end{array}$ \\
\hline 50 & (Mao et al., 2020) & & & & & $\bullet$ & & & $\bullet$ & $\begin{array}{l}\text { Peningkatan kinerja konsensus blockchain dalam kasus } \\
\text { ketelusuran produk teh menggunakan AHP }\end{array}$ \\
\hline 51 & (Hang, Ullah \& Kim, 2020) & & & & $\bullet$ & & & & $\bullet$ & $\begin{array}{l}\text { Penggunaan blockchain untuk data base produk } \\
\text { perikanan }\end{array}$ \\
\hline 52 & (Lin et al., 2020) & $\bullet$ & & & & & $\bullet$ & & & $\begin{array}{l}\text { Ulasan mengenai teknik dan aplikasi blockchain dalam } \\
\text { pertanian }\end{array}$ \\
\hline 53 & $\begin{array}{l}\text { (Putri, Hariadi \& Wibawa, } \\
\text { 2020) }\end{array}$ & & $\bullet$ & & & & & & $\bullet$ & $\begin{array}{l}\text { Penggunaan blockchain dalam menunjang manajemen } \\
\text { rantai pasok produk cabai di Indonesia }\end{array}$ \\
\hline 54 & (Demestichas et al., 2020) & $\bullet$ & & & & & $\bullet$ & & & $\begin{array}{l}\text { Ulasan mengenai sistem penelusuran produk pertanian } \\
\text { menggunakan blockchain }\end{array}$ \\
\hline 55 & (Wang \& Yang, 2020) & $\bullet$ & & & & & & $\bullet$ & & $\begin{array}{l}\text { Ulasan mengenai keamanan produk agrifood } \\
\text { menggunakan blockchain. }\end{array}$ \\
\hline 56 & (Li, Wang \& Li, 2020) & & & & $\bullet$ & & $\bullet$ & & & $\begin{array}{l}\text { Analisis keberlanjutan sistem blockchain dalam } \\
\text { pertanian }\end{array}$ \\
\hline 57 & (Chen, Li \& Li, 2020) & $\bullet$ & & & & & $\bullet$ & & & $\begin{array}{l}\text { Ulasan mengenai digital agricultural democratization } \\
\text { menggunakan blockchain }\end{array}$ \\
\hline 58 & (Zhang, Cao \& Dong, 2020) & $\bullet$ & & & & & $\bullet$ & & & $\begin{array}{l}\text { Ulasan penerapan, teknik serta tantangan riset mengenai } \\
\text { blockchain dan IOT dalam pertanian. }\end{array}$ \\
\hline
\end{tabular}

Berdasarkan Tabel 1 serta Gambar 2 sampai Gambar 5, dapat terlihat bahwa dominasi penelitian terkait blockchain di pertanian adalah sebagai berikut:

(1) Publikasi tertinggi ada di tahun 2020, meskipun publikasi baru sampai bulan Agustus 2020. Penggunaan blockchain pada bidang pertanian menunjukan peningkatan yang diikuti pula peningkatan riset blockchain dan AI pada 2019 dan 2020.

(2) Mayoritas publikasi mengenai blockchain di pertanian berfokus pada topik supply chain management (SCM) (38\%) dan ulasan mengenai teknologi blockchain (36\%)

(3) Mayoritas publikasi (79\%) membahas produk pertanian secara umum. Secara spesifik produk pertanian yang telah diulas sebanyak 14\% meliputi komoditas padi, kedelai, kakao, cabai, susu dan produk perikanan.

(4) Asia masih memiliki dominasi tertinggi (78\%) dalam hal lokasi penelitian penerapan Blockchain. Negara dengan jumlah penelitian tertinggi adalah India (28\%), China $(22 \%)$ dan Spanyol (8\%). Terdapat 2 penelitian dengan lokasi penelitian di Indonesia yang berfokus pada komoditas cabai dan kakao.

(5) Publikasi terkait blockchain dan AI sebanyak $20 \%$ dengan rincian $10 \%$ berupa implementasinya dalam bidang pertanian dan $10 \%$ berupa ulasan, rekomendasi dan tantangan riset dari integrasi tersebut di bidang pertanian.

Hasil analisa deskriptif berdasarkan text mining dari seluruh artikel blockchain dan kecerdasan buatan disajikan dalam Gambar 6. Pada Gambar 6(a), dominasi kata-kata yang muncul adalah blockchain, data, IOT, AI, aplications, technology, system, information, network dan learning Hubungan katakata ini membentuk suatu cluster yang diilustrasikan dalam pohon pada Gambar 6(b). Dalam pohon tersebut aplications, blockchain, AI dan IOT berada dalam sebuah cluster. Konsep blockchain, AI dan IOT dalam artikel-artikel yang ada secara umum merepresentasikan tantangan penelitian di masa depan. Kata technology, system, information, network learning dan data muncul pada cluster lain. Hal ini menunjukan kata-kata tersebut dekat dengan aplikasi blockchain, IOT dan AI.

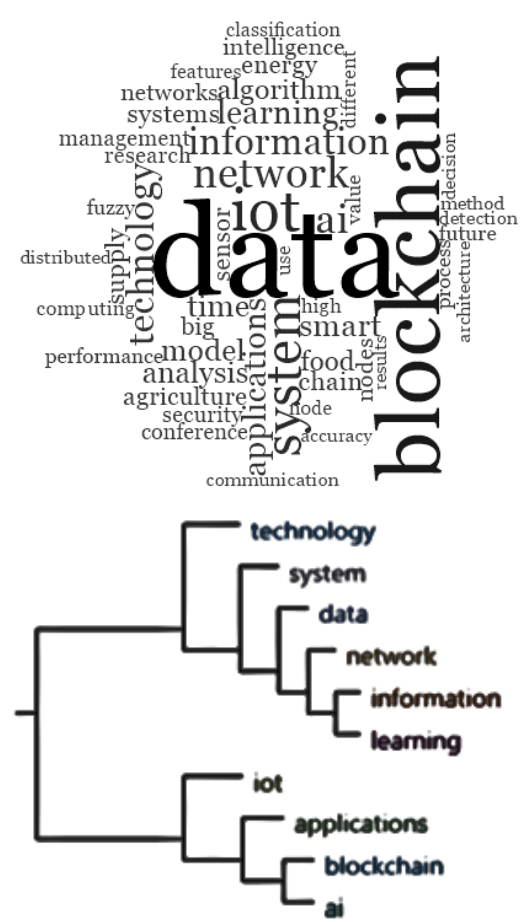

Gambar 6. (a) Word of Cloud; (b) Hasil clustering dalam tree 


\subsection{Hasil Studi Literatur}

Berdasarkan hasil klasifikasi, terdapat 12 artikel terkait blockchain dan kecerdasan buatan di pertanian dengan rincian 6 paper berupa implmentasi serta 6 paper berupa ulasan (survey). Ulasan mengenai 12 artikel ilmiah tersebut disajikan pada Tabel 2.

\begin{tabular}{|c|c|c|}
\hline No & Referensi & Deskripsi \\
\hline 1 & $\begin{array}{l}\text { (Munir, } \\
\text { Bajwa \& } \\
\text { Cheema, } \\
\text { 2019) }\end{array}$ & $\begin{array}{l}\text { - Pengembangan prototype Smart Watering } \\
\text { System (SWS) di Pakistan. } \\
\text { - Sistem berbasis logika fuzzy digunakan } \\
\text { memutuskan tindakan berdasarkan nilai } \\
\text { variabel input, } \\
\text { - Sistem yang diusulkan aman dan efisien } \\
\text { untuk proses penyiraman tanaman. }\end{array}$ \\
\hline 2 & $\begin{array}{l}\text { (Dakshay } \\
\text { ini \& } \\
\text { Balaji } \\
\text { Prabhu, } \\
\text { 2020) }\end{array}$ & $\begin{array}{l}\text { - Integrasi model big data dengan teknologi } \\
\text { blockchain untuk sinkronisasi permintaan } \\
\text { dan penawaran dalam produk pertanian di } \\
\text { India. } \\
\text { - Blockchain digunakan untuk mengurangi } \\
\text { peran perantara (tengkulak). } \\
\text { - Model secara efektif meningkatkan } \\
\text { kualitas sistem pertanian berdasarkan } \\
\text { tingkat kesesuaian permintaan dan } \\
\text { penawaran. }\end{array}$ \\
\hline 3 & $\begin{array}{l}\text { (Khan, } \\
\text { Byun \& } \\
\text { Park, } \\
\text { 2020) }\end{array}$ & $\begin{array}{l}\text { - Pengembangan SCM dalam industri } 4.0 \\
\text { dalam sektor pangan akan lebih optimal } \\
\text { jika diintegrasikan teknologi IOT, } \\
\text { blockchain dan kecerdasan buatan. } \\
\text { - Penggunaan Recurent Neural Network } \\
\text { (RNN) untuk prediksi penjualan produk } \\
\text { pertanian. Optimisasi algoritma genetika } \\
\text { (GA) secara bersama sama untuk } \\
\text { mengoptimalkan parameter model hibrida. } \\
\text { - Model digunakan untuk membantu para } \\
\text { praktisi rantai pasokan untuk mengambil } \\
\text { keputusan sesuai hasil prediksi. }\end{array}$ \\
\hline 4 & $\begin{array}{l}\text { (Yad } \\
\text { al., } 2\end{array}$ & $\begin{array}{l}\text { - Evaluasi pelaksanaan penerapan } \\
\text { blockchain dalam rantai pasok pertanian di } \\
\text { India menggunakan pendekatan Fuzzy. } \\
\text { - Penerapan model evaluasi menggunakan } \\
\text { Total Interpretive Structural Modeling } \\
\text { (TISM), System Dynamics Modelling } \\
\text { (SDM). Hambatan yang ada } \\
\text { dikelompokkan menjadi dalam kelompok } \\
\text { yang cocok menggunakan Fuzzy- } \\
\text { MICMAC. }\end{array}$ \\
\hline 5 & $\begin{array}{l}\text { (Sala } \\
\text { al., } 2(\end{array}$ & $\begin{array}{l}\text { - Memberikan framework yang jelas atas } \\
\text { penerapan AI dan Blockchain di berbagai } \\
\text { bidang termasuk pertanian } \\
\text { - Memberikan taksonomi yang jelas } \\
\text { mengenai penerapan AI dan Blockchain } \\
\text { - Memberikan ulasan yang jelas mengenai } \\
\text { peran AI dalam meningkatkan sistem } \\
\text { blokchain dan ulasan mengenai peran } \\
\text { blockchain dalam memperkuat sistem AI. }\end{array}$ \\
\hline 6 & $\begin{array}{l}\text { (Rabah, } \\
\text { 2018) }\end{array}$ & $\begin{array}{l}\text { - Menggambarkan konsep blockchain, IOT, } \\
\text { AI dan big data di berbagai bidang } \\
\text { - Penerapan blockchain dan AI di pertanian } \\
\text { tidak secara spesifik dijelaskan }\end{array}$ \\
\hline 7 & $\begin{array}{l}\text { (Singh, } \\
\text { Rathore } \\
\text { \& Park, } \\
\text { 2019) }\end{array}$ & $\begin{array}{l}\text { - Mengulas penerapan blockchain, AI dan } \\
\text { IOT di berbagai bidang } \\
\text { - Penerapan blockchain dan AI di pertanian } \\
\text { tidak secara spesifik dijelaskan }\end{array}$ \\
\hline
\end{tabular}

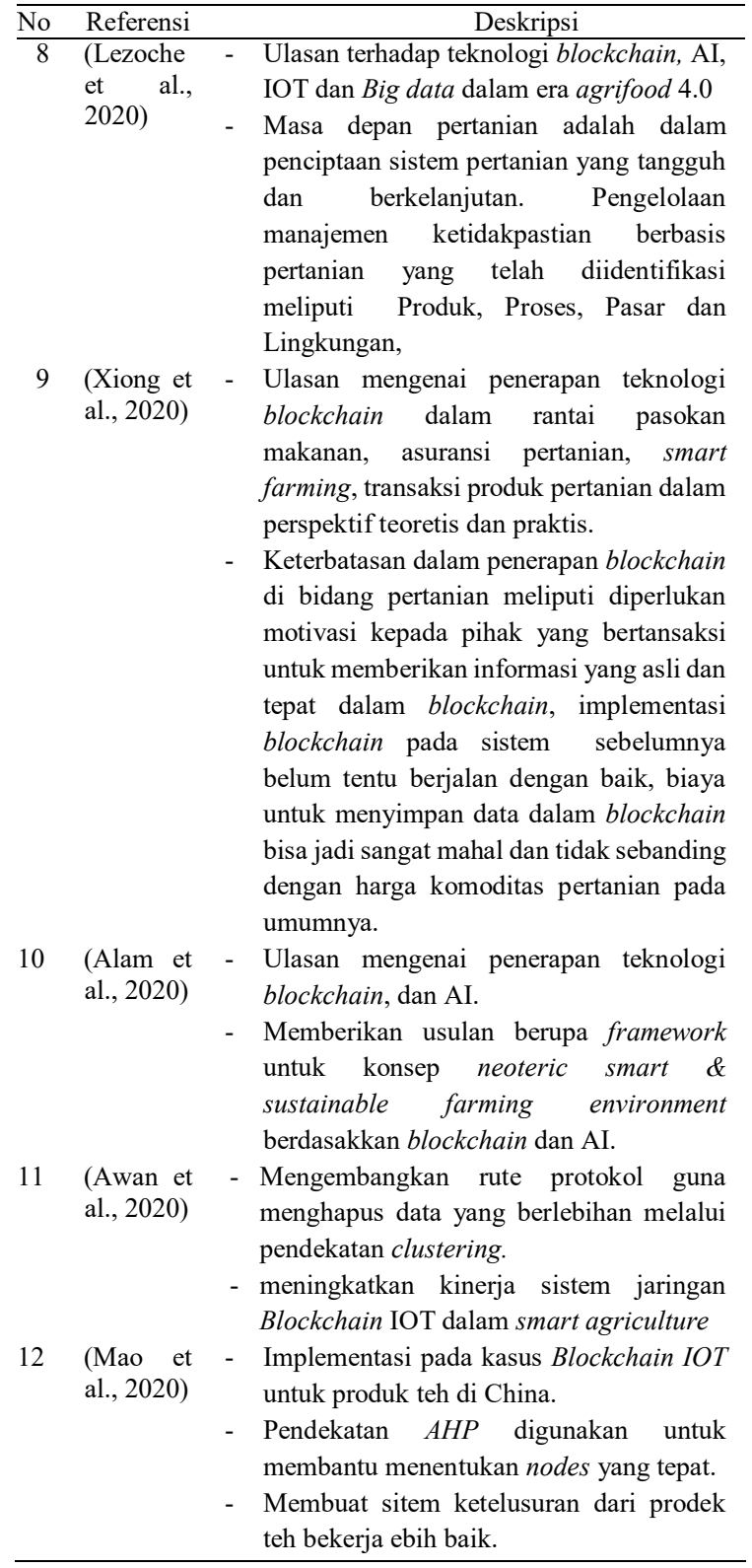

Perpaduan blockchain dan kecerdasan buatan dapat meningkatkan keamanan dan kepercayaan dari suatu sistem cerdas atau dapat pula meningkatkan kinerja sistem blockchain secara cerdas Hal ini merupakan bagian dari konsep blockchain for AI maupun AI for blockchain. konsep blockchain for AI adalah penggunaan blockchain untuk mendukung keamanan data dari sistem AI, sedangkan konsep $A I$ for blockchain merupakan penggunaan AI untuk dapat meningkatkan kinerja blockchain (Salah et al., 2018). Penelitian (Salah et al., 2018) kemudian menjadi rujukan untuk pengembangan konsep blockchain dan kecerdasan buatan termasuk dalam bidang pertanian.

Posisi riset blockchain dan kecerdasan buatan dalam pertanian dapat dilihat pada Gambar 2 dan Gambar 3. Dari Gambar 2 terlihat peningkatan publikasi dari riset blockchain dan kecerdasan buatan dari 1 buah publikasi di tahun 2019 menjadi 5 buah di tahun 2020 dengan total sebanyak 6 buah publikasi. Dari total tersebut 3 artikel masuk dalam konsep 
blockchain for AI dan sisanya masuk dalam konsep AI for Blockchain.

Konsep blockchain for AI dalam bidang pertanian diinisialisasi melalui penelitian (Munir, Bajwa \& Cheema, 2019) dengan menggunakan blockchain dan logika fuzzy pada Smart Watering System (SWS). Penelitian (Dakshayini \& Balaji Prabhu, 2020) telah membuat sistem penunjang keputusan berbasis big data dalam sistem blockchain . Penelitian (Khan, Byun \& Park, 2020) telah menggunakan data dalam teknologi blockchain-IOT untuk memprediksi penjualan produk pertanian menggunakan pendekatan deep learning. Ketiga penelitian tersebut memanfaatkan blockchain sebagai media untuk menyimpan data secara aman serta memanfaatkan data yang ada dengan pendekatan kecerdasan buatan.

Konsep AI for blockchain ditemukan pada tiga penelitian berikut. Penelitian (Awan et al., 2020) menggunakan Emergent Routing Scheme untuk meningkatkan kinerja sistem blockchain - IOT untuk smart agriculture. Penelitian (Mao et al., 2020) menggunakan model analytic hierarchy process (AHP) untuk meningkatkan kinerja dalam proses konsensus blockchain dalam kasus produk teh. Kedua penelitian tersebut memanfaatkan kecerdasan buatan untuk meningkatkan kinerja blockchain yang diterapkan dalam kasus pertanian. Berbeda dengan hal di atas, penelitian (Yadav et al., 2020) menggunakan pendekatan fuzzy untuk mengevaluasi sistem blockchain yang telah berjalan dalam sistem manajemen rantai pasok pertanian.

Dari berbagai penelitian tersebut di atas membuktikan bahwa penggabungan kecerdasan buatan dan blockchain merupakan hal yang mungkin dilakukan. Konsep blockchain for AI maupun AI for blockchain keduanya dapat diimplementasikan secara bersamaan pada bidang pertanian. Penelitian blockchain dan AI dalam pertanian masih didominasi oleh komunitas peneliti Asia yakni India (33\%), Pakistan (33\%), China (14\%) dan Korea (14\%).

Tantangan penelitian ke depan berdasarkan hasil studi literatur secara ringkas disampaikan sebagai berikut:

(1) Penggunaan sistem blockchain oleh seluruh pemangku kepentingan yang terlibat dalam rantai pasok pertanian.

(2) Peningkatan proses bisnis sistem.

(3) Peningkatan peran pemerintah dan kepercayaan antar pemangku kepentingan.

(4) Integrasi teknologi blockchain, kecerdasan buatan, IOT dan big data di bidang pertanian.

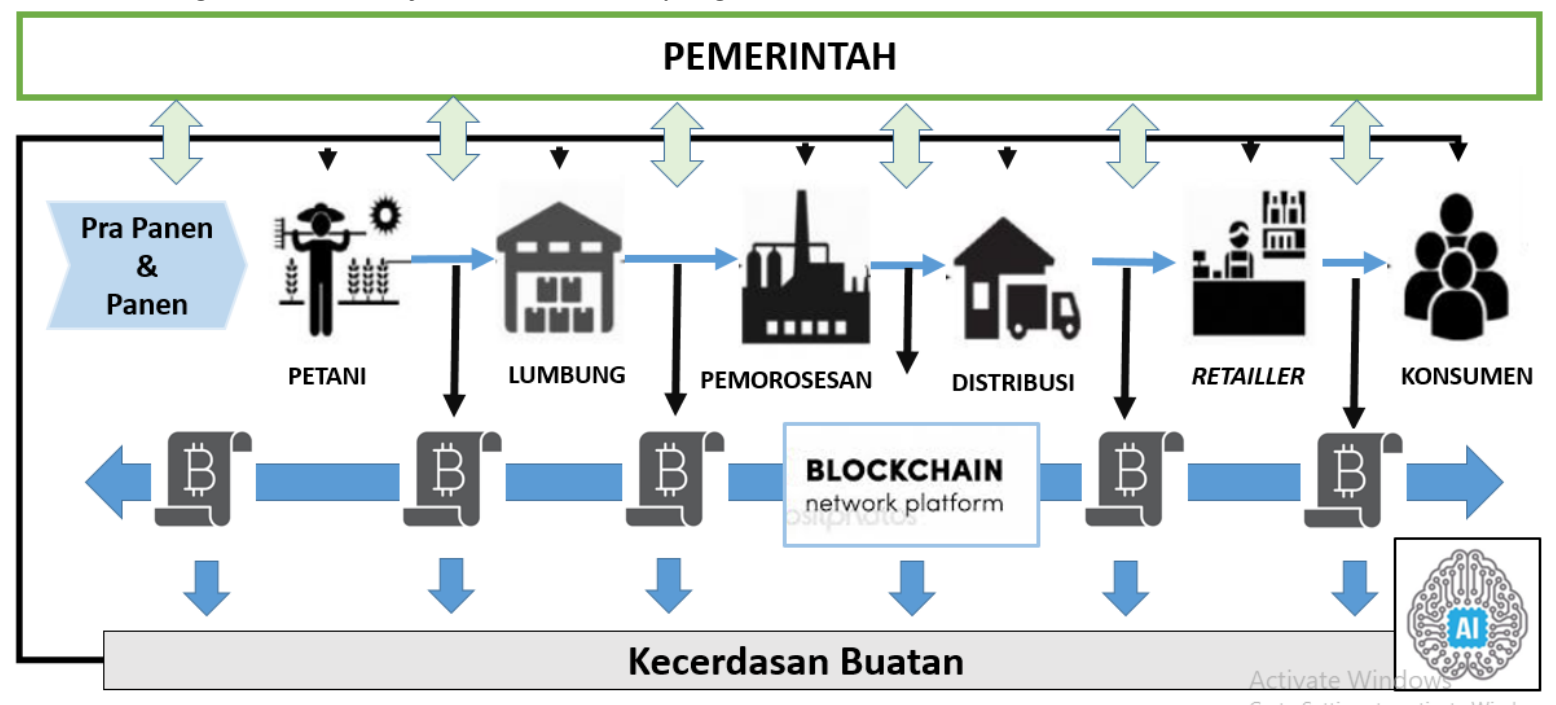

Gambar 7. Usulan Pengembangan Riset Blockchain dan AI untuk komoditas Padi di Indonesia

\subsection{Usulan Pengembangan}

Berdasarkan tantangan penelitian yang ditemukan dan dengan mempertimbangkan kondisi pertanian di Indonesia, maka diusulkan suatu sistem yang merupakan salah satu penerapan AI dan blockchain di bidang pertanian. Pemilihan implementasi pada menajemen rantai pasok dikarenakan dominasi penelitian yang telah tersedia. Gambar 7 merupakan ilustrasi integrasi AI dan blockchain di pertanian. Ilustrasi tersebut merupakan pengembangan dari model (Kumar \& Iyengar, 2018) dalam komoditas beras. Beberapa fitur kecerdasan buatan yang dapat ditambahkan meliputi prediksi harga (Vohra, Pandey \& Khatri, 2019) dan prediksi hasil panen (Liakos et al., 2018). Perangkat IOT juga dapat ditambahkan dalam sistem tersebut berupa sensor dan perangkat penunjang lainnya. Model prediksi dapat diperoleh dari data base dalam sistem blockchain yang kemudian dipelajari berdasarkan konsep kecerdasan buatan. Hasil pembelajaran berupa prediksi disampaikan kepada seluruh aktor yang membutuhkan. Seluruh data yang tersimpan akan menjadi big data dan mendorong untuk diterapkannya manajemen big data dalam sistem blockchain (Karafiloski, 2017).

Dalam kasus rantai pasok pertanian di Indonesia, seringkali ditemukan perantara (broker) 
tengkulak) (Widodo, Prihadianto \& Hartanto, 2018) sehingga membuat panjangnya kondisi rantai pasok yang ada (Apriadi \& Saputra, 2017). Penggunaan sistem blockchain dalam manajemen rantai pasok dan penggunaan sistem e-commerce dapat meminimumkan peran perantara. Hal ini dapat bermuara kepada peningkatan kesejahteraan petani. Konsumen juga diuntungkan dengan menurunnya harga jual komoditas pertanian (Reddy, Aravind Reddy \& Sashi Rekha, 2019), (Widodo, Prihadianto $\&$ Hartanto, 2018). Adanya sistem tersebut juga akan mempermudah pemerintah untuk memantau harga komoditas pertanian tertentu yang berpengaruh terhadap inflasi.

\section{KESIMPULAN}

Integrasi blockchain dan kecerdasan buatan memiliki rasionalisasi ilmiah yang tinggi. Artinya konsep tersebut dapat diimplementasikan diberbagai bidang. Peluang penelitian dengan mengintegrasikan kedua teknologi tersebut masih terbuka lebar khususnya dibidang pertanian.

Hasil kajian kritis memberikan posisi riset terkait teknologi blockchain dan kecerdasan buatan dalam bidang pertanian. Secara keseluruhan riset mengenai teknologi blockchain dalam pertanian masih didominasi dalam hal penerapannya pada bidang manajemen rantai pasok pertanian (36\%). Riset mengenai blockchain dan AI dalam pertanian sebanyak $20 \%$ dengan rincian $10 \%$ berupa ulasan dan $10 \%$ berupa penerapan. Dalam hal penerapan kedua teknologi tersebut, terdapat $5 \%$ penelitian menggunakan menggunakan blockchain untuk peningkatan keamanan data pada sistem cerdas (Blockchain for AI) dan terdapat 5\% penelitian menggunakan AI untuk peningkatan kinerja blockchain (AI for blockchain). Penelitian mengenai penerapan blockchain dan AI dalam pertanian didominasi oleh peneliti di Asia seperti India (33\%), Pakistan (33\%), China (14\%) dan Korea (14\%).

Peluang kebaruan riset pada integrasi AI dan Blockchain dibidang pertanian masih terbuka dengan luas. Berbagai macam sistem AI dapat digunakan sesuai konsep smart farming. Teknologi blockchain dapat digunakan untuk meningkatkan keamanan data dari sistem AI yang selama ini masih tersentralisasi. Saran untuk kelanjutan penelitian adalah dengan penggunaan teknologi yang tepat dan sesuai dengan kebutuhan pengguna sehingga teknologi yang dikembangkan dapat bermanfaat bagi seluruh pemangku kepentingan.

\section{UCAPAN TERIMA KASIH}

Ucapan terimakasih penulis sampaikan kepada Program Studi Doktoral Ilmu Komputer IPB University dan Program Studi Ilmu Komputer Universitas Pakuan.

\section{DAFTAR PUSTAKA}

ALAM, M.A., AHAD, A., ZAFAR, S. \& TRIPATHI, G., 2020. a neoteric smart \& sustainable farming environment incorporating blockchain-based artificial intelligence approach. Cryptocurrencies \& Blockchain Technology Applications, p.197. https://doi.org/10.1002/9781119621201.ch11

ALMEIDA, O.B.-, CARDENAS-RODRIGUEZ, M., SAMANIEGO-COBO, T., FERRUZOLAGÓMEZ, E., CABEZAS-CABEZAS, R. \& BAZÁN-VERA, W., 2018. Blockchain in agriculture: A systematic literature review. In: Communications in Computer \& Information Science. Springer Verlag.pp.44-56. https://doi.org/10.1007/978-3-030-00940-3_4

ANTONUCCI, F., FIGORILLI, S., COSTA, C., PALLOTTINO, F., RASO, L. \& MENESATTI, P., 2019. A review on blockchain applications in the agri-food sector. Journal of the Science of Food \& Agriculture. https://doi.org/10.1002/jsfa.9912

APRIADI, D. \& SAPUTRA, A.Y., 2017. E-Commerce Berbasis Marketplace Dalam Upaya Mempersingkat Distribusi Penjualan Hasil Pertanian. Jurnal RESTI (Rekayasa Sistem dan Teknologi https://doi.org/10.29207/resti.v1i2.36

ARENA, A., BIANCHINI, A., PERAZZO, P., VALLATI, C. \& DINI, G., 2019. BRUSCHETTA: An IoT blockchain-based framework for certifying extra virgin olive oil supply chain. In: Proceedings - 2019 IEEE International Conference on Smart Computing, SMARTCOMP 2019. https://doi.org/10.1109/SMARTCOMP.2019.000 $\underline{49}$

AWAN, S.H., AHMED, S., NAWAZ, A., MAGHDID, S.S., ZAMAN, K., KHAN, M.Y.A., NAJAM, Z. \& IMRAN, S., 2020. BlockChain with IoT, an emergent routing scheme for smart agriculture. International Journal of Advanced Computer Science \& Applications. https://doi.org/10.14569/IJACSA.2020.0110457

BANNERJEE, G., SARKAR, U., DAS, S. \& GHOSH, I., 2018. Artificial Intelligence in Agriculture: A Literature Survey. International Journal of Scientific Research in Computer Science Applications \& Management Studies, [online] 7(3). Available at: <www.ijsrcsams.com>.

BORAH, M.D., NAIK, V.B., PATGIRI, R., BHARGAV, A., PHUKAN, B. \& BASANI, S.G.M., 2020. Supply Chain Management in Agriculture Using Blockchain \& IoT. https://doi.org/10.1007/978-981-13-8775-3 11

BORDEL, B., MARTIN, DI., ALCARRIA, R. \& ROBLES, T., 2019. A Blockchain-based Water Control System for the Automatic Management of Irrigation Communities. In: 2019 IEEE International Conference on Consumer Electronics, ICCE 2019. https://doi.org/10.1109/ICCE.2019.8661940 
CARBONE, A., DAVCEV, D., MITREKI, K., LJUPCO, K. \& STANKOVSKI, V., 2018. Blockchain based Distributed Cloud Fog Platform for IoT Supply Chain Management. https://doi.org/10.15224/978-1-63248-144-3-37

CASADO, V.R., PRIETO, J., LA PRIETA, F. DE \& CORCHADO, J.M., 2018. How blockchain improves the supply chain: Case study alimentary supply chain. In: Procedia Computer Science. https://doi.org/10.1016/j.procs.2018.07.193

CASINO, F., DASAKLIS, T.K. \& PATSAKIS, C., 2019. A systematic literature review of blockchain-based applications: Current status, classification \& open issues. Telematics \& Informatics, https://doi.org/10.1016/j.tele.2018.11.006

CHEN, Y., LI, Y. \& LI, C., 2020. Electronic agriculture, blockchain \& digital agricultural democratization: Origin, theory \& application. Journal of Cleaner Production. https://doi.org/10.1016/j.jclepro.2020.122071

CHINNAIYAN, R. \& BALACHANDAR, S., 2020. Reliable Administration Framework of Drones \& IoT Sensors in Agriculture Farmstead using Blockchain \& Smart Contracts. In: ACM International Conference Proceeding Series. https://doi.org/10.1145/3378904.3378918

DAKSHAYINI, M. \& BALAJI PRABHU, B. V., 2020. An Effective Big Data \& Blockchain (BDBC) Based Decision Support Model for Sustainable Agriculture System. https://doi.org/10.1007/978-3-030-19562-5_8

DANIEL, D. \& IFEJIKA SPERANZA, C., 2020. The Role of Blockchain in Documenting Land Users' Rights: The Canonical Case of Farmers in the Vernacular Land Market. Frontiers in Blockchain. https://doi.org/10.3389/fbloc.2020.00019

DAVE, D., PARIKH, S., PATEL, R. \& DOSHI, N., 2019. A survey on blockchain technology \& its proposed solutions. In: Procedia Computer Science.

https://doi.org/10.1016/j.procs.2019.11.017

DEMESTICHAS, K., PEPPES, N., ALEXAKIS, T. \& ADAMOPOULOU, E., 2020. Blockchain in agriculture traceability systems: A review. Applied Sciences (Switzerland). https://doi.org/10.3390/app10124113

DINH, T.N. \& THAI, M.T., 2018. AI \& Blockchain: A Disruptive Integration. Computer. https://doi.org/10.1109/MC.2018.3620971

FAO, 2019. World Food \& Agriculture Statistical Pocketbook. Rome: Food \& Agriculture Organization of the United Nations.

FERRAG, M.A., SHU, L., YANG, X., DERHAB, A. \& MAGLARAS, L., 2020. Security \& Privacy for Green IoT-Based Agriculture: Review, Blockchain Solutions, \& Challenges. IEEE Access. https://doi.org/10.1109/ACCESS.2020.2973178

GE, L., BREWSTER, C., SPEK, J., SMEENK, A. \& TOP, J., 2017. Findings from the pilot study
Blockchain for Agriculture \& Food. [online] Wageningen Economic Research. Available at: $<$ www.wur.eu/economic-research>.

HANG, L., ULLAH, I. \& KIM, D.H., 2020. A secure fish farm platform based on blockchain for agriculture data integrity. Computers \& Electronics in Agriculture https://doi.org/10.1016/j.compag.2020.105251

HUA, J., WANG, X., KANG, M., WANG, H. \& WANG, F.Y., 2018. Blockchain Based Provenance for Agricultural Products: A Distributed Platform with Duplicated \& Shared Bookkeeping. In: IEEE Intelligent Vehicles Symposium, Proceedings. Institute of Electrical \& Electronics Engineers Inc.pp.97-101. https://doi.org/10.1109/IVS.2018.8500647

IPB, 2019. Pengembangan Penelitian Agro-Maritim 4.0. 1st ed. IPB Press.

ISWARI, D.A., ARKEMAN, Y. \& MUSLICH, M., 2019. Analisis Dan Desain Rantai Pasok Kakao Berbasis Blockchain. JURNAL AGRI-TEK : Jurnal Penelitian Ilmu-Ilmu Eksakta, 20(2). https://doi.org/10.33319/agtek.v20i2.55

KAMBLE, S.S., GUNASEKARAN, A. \& SHARMA, R., 2019. Modeling the blockchain enabled traceability in agriculture supply chain. International Journal of Information Management. https://doi.org/10.1016/j.ijinfomgt.2019.05.023

KAMBLE, S.S., GUNASEKARAN, A. \& SHARMA, R., 2020. Modeling the blockchain enabled traceability in agriculture supply chain. International Journal of Information Management. https://doi.org/10.1016/j.ijinfomgt.2019.05.023

KAMILARIS, A., FONTS, A. \& PRENAFETABOLD'Y, F.X., 2019. The rise of blockchain technology in agriculture \& food supply chains. Trends in Food Science \& Technology. https://doi.org/10.1016/j.tifs.2019.07.034

KARAFILOSKI, E., 2017. BLOCKCHAIN SOLUTIONS FOR BIG DATA CHALLENGES IEEE EUROCON 17th International Conference, (July), pp.763-768. https://doi.org/10.1109/EUROCON.2017.801121 $\underline{3}$

KASTEN, J., 2020. BLOCKCHAIN ON THE FARM: A SYSTEMATIC LITERATURE REVIEW. Journal of Strategic Innovation \& Sustainability, $15(2)$, https://doi.org/10.33423/jsis.v15i2.2893

KHAN, P.W., BYUN, Y.-C. \& PARK, N., 2020. IoTBlockchain Enabled Optimized Provenance System for Food Industry 4.0 Using Advanced Deep Learning. Sensors, 20(10), p.2990. https://doi.org/10.3390/s20102990

KIM, H. \& LASKOWSKI, M., 2018. Agriculture on the Blockchain: Sustainable Solutions for Food, Farmers, \& Financing. SSRN Electronic Journal. https://doi.org/10.2139/ssrn.3028164 
KLERKX, L., JAKKU, E. \& LABARTHE, P., 2019. A review of social science on digital agriculture, smart farming \& agriculture 4.0: New contributions \& a future research agenda. NJAS Wageningen Journal of Life Sciences, https://doi.org/10.1016/j.njas.2019.100315

KUMAR, M. \& IYENGAR, S.N., 2018. Blockchain: An Emerging Paradigm in Rice Supply Chain Management. International Journal of Engineering Research in Computer Science \& Engineering (IJERCSE).

LENG, K., BI, Y., JING, L., FU, H.C. \& Van Nieuwenhuyse, I., 2018. Research on agricultural supply chain system with double chain architecture based on blockchain technology. Future Generation Computer Systems. https://doi.org/10.1016/j.future.2018.04.061

LEZOCHE, M., PANETTO, H., KACPRZYK, J., HERNANDEZ, J.E. \& ALEMANY DÍAZ, M.M.E., 2020. Agri-food 4.0: A survey of the Supply Chains \& Technologies for the Future Agriculture. Computers in Industry. https://doi.org/10.1016/j.compind.2020.103187

LI, X., WANG, D. \& LI, M., 2020. Convenience analysis of sustainable E-agriculture based on blockchain technology. Journal of Cleaner Production. https://doi.org/10.1016/j.jclepro.2020.122503

LIAKOS, K.G., BUSATO, P., MOSHOU, D., PEARSON, S. \& BOCHTIS, D., 2018. Machine learning in agriculture: A review. Sensors (Switzerland). https://doi.org/10.3390/s18082674

LIN, W., HUANG, X., FANG, H., WANG, V., HUA, Y., WANG, J., YIN, H., YI, D. \& YAU, L., 2020. Blockchain Technology in Current Agricultural Systems: From Techniques to Applications. IEEE Access. https://doi.org/10.1109/ACCESS.2020.3014522

LIN, Y.-P., PETWAY, J., ANTHONY, J., MUKHTAR, H., LIAO, S.-W., CHOU, C.-F. \& HO, Y.-F., 2017. Blockchain: The Evolutionary Next Step for ICT E-Agriculture. Environments. https://doi.org/10.3390/environments4030050

LUCENA, P., BINOTTO, A.P.D., MOMO, F. DA S. \& KIM, H., 2018. A Case Study for Grain Quality Assurance Tracking based on a Blockchain Business Network. symposium on Foundations \& Applications of Blockchain, [online] (FAB), pp.16. Available at: $<$ http://arxiv.org/abs/1803.07877>.

MAO, T., FAN, Y., YANG, J. \& WEI, H., 2020. A Research on Tea Traceability Consensus Mechanism Based on Blockchain Technology. In: New Developments of IT, IoT \& ICT Applied to Agriculture. Springer.pp.129-137. https://doi.org/10.1007/978-981-15-5073-7_13

MIRABELLI, G. \& SOLINA, V., 2020. Blockchain \& agricultural supply chains traceability: Research trends \& future challenges. In: Procedia
Manufacturing.

https://doi.org/10.1016/j.promfg.2020.02.054

MISTRY, I., TANWAR, S., TYAGI, S. \& KUMAR, N., 2020. Blockchain for 5G-enabled IoT for industrial automation: A systematic review, solutions, \& challenges. Mechanical Systems \& Signal Processing. https://doi.org/10.1016/j.ymssp.2019.106382

MUNIR, M.S., BAJWA, I.S. \& CHEEMA, S.M., 2019. An intelligent \& secure smart watering system using fuzzy logic \& blockchain. Computers \& Electrical Engineering. https://doi.org/10.1016/j.compeleceng.2019.05.0 $\underline{06}$

NAKAMOTO, S., 2008. Bitcoin: A Peer-to-Peer Electronic Cash SyNakamoto, S. (2008). Bitcoin: A Peer-to-Peer Electronic Cash System. Consulted, 1-9. doi:10.1007/s10838-008-90620stem. Consulted.

NAZAROV, A.D., SHVEDOV, V. V. \& SULIMIN, V. V., 2019. Blockchain technology \& smart contracts in the agro-industrial complex of Russia. In: IOP Conference Series: Earth \& Environmental Science. https://doi.org/10.1088/1755-1315/315/3/032016

O'MARA-EVES, A., THOMAS, J., MCNAUGHT, J., MIWA, M. \& ANANIADOU, S., 2015. Using text mining for study identification in systematic reviews: A systematic review of current approaches. Systematic Reviews, 4(1). https://doi.org/10.1186/s13643-015-0031-5

PAPA, S.F., 2017. Use of Blockchain Technology in Agribusiness: Transparency \& Monitoring in Agricultural Trade. https://doi.org/10.2991/msmi-17.2017.9

PATIL, A.S., TAMA, B.A., PARK, Y.\& RHEE, K.H., 2018. A framework for blockchain based secure smart green house farming. In: Lecture Notes in Electrical Engineering. https://doi.org/10.1007/978-981-10-7605-3_185

PUTRI, A.N., HARIADI, M. \& WIBAWA, A.D., 2020. Smart Agriculture Using Supply Chain Management Based on Hyperledger Blockchain. In: IOP Conference Series: Earth \& Environmental Science. https://doi.org/10.1088/1755-1315/466/1/012007

RABAH, K., 2018. Convergence of AI, IoT, Big Data \& Blockchain: A Review. The Lake Institute Journal, [online] 1(1), pp.1-18. Available at: $<$ www.thelakeinstitute.org $>$.

REDDY, H., ARAVIND REDDY, Y. \& SASHI REKHA, K., 2019. Blockchain: To improvise economic efficiency \& supply chain management in agriculture. International Journal of Innovative Technology \& Exploring Engineering, 8(12), pp.4999-5004. https://doi.org/10.35940/ijitee.L3749.1081219 
SALAH, K., NIZAMUDDIN, N., JAYARAMAN, R. \& OMAR, M., 2019. Blockchain-Based Soybean Traceability in Agricultural Supply Chain. IEEE Access, 7, pp.73295-73305. https://doi.org/10.1109/ACCESS.2019.2918000

SALAH, K., REHMAN, M.H.U., NIZAMUDDIN, N. \& AL-FUQAHA, A., 2018. Blockchain for AI: Review \& open research challenges. IEEE Access. https://doi.org/10.1109/ACCESS.2018.2890507

SALMAN, T., ZOLANVARI, M., ERBAD, A., JAIN, R. \& SAMAKA, M., 2019. Security services using blockchains: A state of the art survey. IEEE Communications Surveys \& Tutorials. https://doi.org/10.1109/COMST.2018.2863956

SHAHID, A., ALMOGREN, A., JAVAID, N., ALZAHRANI, F.A., ZUAIR, M. \& ALAM, M., 2020a. Blockchain-Based Agri-Food Supply Chain: A Complete Solution. IEEE Access. https://doi.org/10.1109/ACCESS.2020.2986257

SHAHID, A., SARFRAZ, U., MALIK, M.W., IFTIKHAR, M.S., JAMAL, A. \& JAVAID, N., 2020b. Blockchain-Based Reputation System in Agri-Food Supply Chain. In: Advances in Intelligent Systems \& Computing. https://doi.org/10.1007/978-3-030-44041-1_2

SHINGH, S., KAMALVANSHI, V., GHIMIRE, S. \& BASYAL, S., 2020. Dairy Supply Chain System Based on Blockchain Technology. Asian Journal of Economics, Business \& Accounting. https://doi.org/10.9734/ajeba/2020/v14i230189

SINGH, S.K., RATHORE, S. \& PARK, J.H., 2019. BlockIoTIntelligence: A Blockchain-enabled Intelligent IoT Architecture with Artificial Intelligence. Future Generation Computer Systems.

https://doi.org/10.1016/j.future.2019.09.002

SISODIYA, V.S. \& GARG, H., 2020. A Comprehensive study of Blockchain \& its various Applications.

https://doi.org/10.1109/PARC49193.2020.23665 9

TIAN, F., 2016. An agri-food supply chain traceability system for China based on RFID \& blockchain technology. In: 2016 13th International Conference on Service Systems \& Service Management, ICSSSM 2016.

TIWARI, U., 2020. Application of Blockchain in AgriFood Supply Chain. Britain International of Exact Sciences (BIoEx) Journal. https://doi.org/10.33258/bioex.v2i2.233

TSE, D., ZHANG, B., YANG, Y., CHENG, C. \& MU, H., 2017. Blockchain application in food supply information security. In: IEEE International Conference on Industrial Engineering \& Engineering Management. https://doi.org/10.1109/IEEM.2017.8290114

VARDI, M.Y., 2012. Artificial intelligence: Past \& future. Communications of the ACM, https://doi.org/10.1145/2063176.2063177
VOHRA, A., PANDEY, N. \& KHATRI, S.K., 2019. Decision Making Support System for Prediction of Prices in Agricultural Commodity. Proceedings - 2019 Amity International Conference on Artificial Intelligence, AICAI 2019, pp.345-348. https://doi.org/10.1109/AICAI.2019.8701273

WANG, Y. \& YANG, Y., 2020. Research on Agricultural Food Safety Based on Blockchain Technology. In: Journal of Physics: Conference Series.

https://doi.org/10.1088/17426596/1606/1/012013

WIDODO, E., PRIHADIANTO, R.D. \& HARTANTO, D., 2018. Multi period pricing for managing local fruit supply chain. In: MATEC Web of Conferences. https://doi.org/10.1051/matecconf/201815401049

WU, H. TE \& TSAI, C.W., 2019. An intelligent agriculture network security system based on private blockchains. Journal of Communications $\&$ Networks. https://doi.org/10.1109/JCN.2019.000043

XIE, C., SUN, Y. \& LUO, H., 2017. Secured Data Storage Scheme Based on Block Chain for Agricultural Products Tracking. In: Proceedings 2017 3rd International Conference on Big Data Computing \& Communications, BigCom 2017. https://doi.org/10.1109/BIGCOM.2017.43

XIONG, H., DALHAUS, T., WANG, P. \& HUANG, J., 2020. Blockchain Technology for Agriculture: Applications \& Rationale. Frontiers in Blockchain. https://doi.org/10.3389/fbloc.2020.00007

YADAF, V.S. \& SINGH, A., 2019. A systematic literature review of blockchain Technology in Agriculture. Digital Communications \& Networks, pp.973-981.

YADAV, V.S., SINGH, A.R., RAUT, R.D. \& GOVINDARAJAN, U.H., 2020. Blockchain technology adoption barriers in the Indian agricultural supply chain: an integrated approach. Resources, Conservation \& Recycling, 161, p.104877. https://doi.org/10.1016/j.resconrec.2020.104877

ZHANG, X., CAO, Z. \& DONG, W., 2020. Overview of Edge Computing in the Agricultural Internet of Things: Key Technologies, Applications, Challenges. IEEE Access. https://doi.org/10.1109/ACCESS.2020.3013005

ZHENG, Z., XIE, S., DAI, H., CHEN, X. \& WANG, H., 2017. An Overview of Blockchain Technology: Architecture, Consensus, \& Future Trends. In: Proceedings - 2017 IEEE 6th International Congress on Big Data, BigData Congress 2017. https://doi.org/10.1109/BigDataCongress.2017.8 $\underline{5}$ 